\title{
(1) \\ KคRMAPATI \\ Pengembangan Modul Ajar Pemrograman Web Dengan Konsep Scientific Berorientasi Project Based Learning di SMK Negeri 2 Seririt
}

\author{
Ketut Sri Addalena ${ }^{1}$, Luh Putu Eka Damayanthi ${ }^{2}$,Dessy Seri Wahyuni ${ }^{3}$, I Made Agus Wirawan ${ }^{4}$ \\ Pendidikan Teknik Informatika \\ Universitas Pendidikan Ganesha \\ Singaraja, Bali \\ E-mail:sriaddalena@gmail.com ${ }^{1}$,ekadamayanthi@ rocketmail.com² ${ }^{2}$ dsy.wahyuni@gmail.com ${ }^{3}$, \\ kadekjus@yahoo.com ${ }^{4}$
}

Abstrak-Penelitian ini bertujuan untuk (1) Merancang Modul Ajar Pemprograman Web dengan Konsep Scientifict berorientasi Project Based Learning. (2) Mengimplementasikan Modul Ajar Pemprograman Web dengan Konsep Scientifict berorientasi Project Based Learning

Jenis penelitian yang digunakan dalam penelitian ini adalah Penelitian dan Pengembangan (Research and Development atau $R \& D)$ dengan model ADDIE (Analysis, Design, Development, Implementation, Evaluation). Penelitian ini melibatkan siswa Multimedia SMK Negeri 2 Seririt tahun ajaran 2014/2015. Data tentang sumber belajar siswa diperoleh dengan menggunakan metode wawancara. Validasi modul ajar pemprograman web diperoleh dengan menggunakan metode angket. Data yang diperoleh tersebut dianalisis secara deskriptif.

Pengembangan modul ajar pemprograman web dengan konsep scientific berorientasi PjBL. Hasil analisis data respon siswa menunjukkan siswa memberikan penilaian dengan rata-rata persentase $89 \%$ sehingga jika dikonversikan persentase tersebut dalam kualifikasi baik.

Kata-kata kunci : modul, PjBL, scientific, web

Abstract-This research aims to(1) Design instructional module program concepts scientifict orientation site with project based learning. (2) Implementing Instructional Module Programming the Web with Scientifict oriented concept of Project Based Learning

This type of research use in this study is the research ad development (Research and development $\left.\begin{array}{llllll}\text { or } & R & \& & D\end{array}\right)$ With the model ADDIE (Analysis,Desaign,Development,Implementation,Evalu ation). This research involve multimedia students of
SMK Negeri 2 Seririt on academic years 2014/2015.Data of student learning resource obtained by using interviews. Validation of web program teaching module obtained by using questionnaires.the data obtained are analyzed descriptively.

Teaching module development web programming with PJBL oriented scientific concept. The results of the data analysis of student responses indicate the student to provide an assessment with an average percentage of $89 \%$, so if the percentage is converted into a good qualification.

Key words: module, PJBL, scientific, web

\section{PENDAHULUAN}

SMK Negeri 2 Seririt merupakan sekolah menengah kejuruan yang terletak di Desa Banjarasem, Kecamatan Seririt, Program keahlian yang telah ada sampai saat ini di SMK Negeri 2 Seririt yakni Program Keahlian Multimedia yang bergerak dibidang teknik pengeditan Audio Video visual, Program Keahlian Teknik Komputer dan Jaringan yang bergerak dibidang teknik komputerisasi dan jaringan, serta Program Keahlian Akuntansi yang bergerak dibidang teknik pengolahan laba dan rugi. Pada Program Keahlian Multimedia, salah satu mata pelajaran yang diajarkan adalah Pemrograman Web, dengan kompetensi yang dituntut yakni siswa dapat memahami secara mendalam konsep dasar pemrograman web baik secara teori maupun praktiknya. Secara umum tuntutan kompetensi yang diharapkan dari siswa terkait dengan mata pelajaran ini belum sepenuhnya tercapai. Salah satu hal yang menyebabkan adalah dalam proses pembelajaran guru masih menjadi satu-satunya sumber informasi bagi siswa. Guru dalam menjelaskan materi di depan kelas lebih banyak menggunakan ceramah sedangkan siswa lebih banyak menjadi pendengar yang pasif dengan sesekali mencatat apa yang disampaikan oleh guru. Jika 


\section{ISSN 2252-9063 \\ Kumpulan Artikel MahasiswaPendidikanTeknikInformatika}

(KARMAPATI)

KARMAPATI

dikaitkan dengan tuntutan kurikulum 2013 yang menekankan pada student center, hal itu tentu tidak sesuai dengan tuntutan kurikulum 2013. Selain itu sumber belajar lainnya seperti buku maupun modul ajar masih sangat terbatas di sekolah ini. Siswa biasanya hanya memperoleh pengetahuan dengan menyalin materi dan mendengarkan ceramah dari guru sehingga berdampak pada rendahnya pemahan konsep siswa, dan ketika dihadapkan pada kegiatan praktikum sebagian dari siswa belum bisa menyelesaikannya secara mandiri.

Hal ini juga diperkuat dari hasil wawancara dengan salah seorang guru di SMK Negeri 2 Seririt, selama ini dalam proses pembelajaran guru belum menggunakan modul ajar sebagai panduan belajar, sumber belajar yang digunakan hanya didapat dari internet dan dari pengetahuan sendiri yang dimiliki oleh guru pengajar, sehingga materi belum terorganisasi dengan baik, dan ketika siswa diberikan tugas oleh guru, siswa mengalami kendala yaitu tidak adanya bahan ajar yang bisa dibaca siswa saat dirumah dan untuk bisa akses internet masih sangat terbatas. Menyikapi dari permasalahan sumber belajar yang kurang, maka diperlukannya suatu solusi sehingga siswa dapat seoptimal mungkin untuk terlibat dalam proses belajar mengajar baik di sekolah maupun dirumah. Salah satu upaya yang dapat di lakukan adalah melalui pengembangan modul ajar. Modul merupakan bahan belajar yang dirancang secara sistematis berdasarkan kurikulum tertentu dan dikemas dalam bentuk satuan pembelajaran terkecil dan memungkinkan dipelajari secara mandiri dalam satuan waktu tertentu (Purwanto $\mathrm{dkk}, 2007)$.

Modul ajar yang akan dikembangkan yakni modul ajar dengan konsep pendekatan Scientific dimana siswa dapat menggunakan modul ajar ini sebagai media pembelajaran dalam proses belajarmengajar dengan teknik membaca dan memahami materi secara cepat. Konsep Scientific adalah konsep mengajar dengan menerapkan karakteristik ilmiah yang menyentuh tiga ranah yaitu sikap (afektif), pengetahuan (kognitif), keterampilan (psikomotor). Dengan proses yang demikian diharapkan hasil belajar melahirkan peserta didik yang produktif kreatif, inovatif dan efektif melalui penguatan sikap dan keterampilan dan pengetahuan yang terintegrasi, (Kemendikbud, 2013). Dalam mengembangkan modul ini penulis menggunakan konsep scientific dengan model Project Based Learning (Pembelajaran berbasis proyek), karena proses pembelajaran yang berfokus pada konsep yang melibatkan siswa dalam kegiatan pemecahan masalah berbasis proyek untuk menghasilkan produk karya yang bernilai serta karakteristik dari materi lebih menekankan pada proses pembelajaran praktikum untuk dapat memahami materi yang disampaikan sehingga tujuan dari proses pembelajaan dapat tercapai dengan baik.

\section{Volume 7, Nomor 3, Tahun 2018}

Pembelajaran Berbasis Proyek merupakan model pembelajaran yang berfokus pada konsep-konsep dan prinsip-prinsip utama dari suatu disiplin, melibatkan siswa dalam kegiatan pemecahan masalah dan tugastugas bermakna lainnya, memberi peluang siswa bekerja secara otonom, mengkonstruk belajaran mereka sendiri dan punjaknya menghasilkan produk karya seni yang bernilai dan realistik. Model pembelajaran project based learning merupakan salah satu pendekatan pembelajaran yang memiliki karakteristik pembelajaran scientific. Pembelajaran Berbasis Proyek dirancang untuk digunakan pada permasalahan kompleks yang diperlukan peserta didik dalam melakukan insvestigasi dan pemahaman. PjBL merupakan investigasi mendalam tentang sebuah topik dunia nyata, hal ini akan berharga bagi atensi dan usaha peserta didik, guru dan peserta didik perlu memainkan peran yang berbeda dari proses Pembelajaran. Untuk keberhasilan pembelajaran diperlukan waktu khusus untuk menyampaikan intruksi pembelajaran. Pada pelaksanaan awal PjBL guru harus mempersiapkan skenario pembelajaran yang matang (Karim J Nasr, 2004)

Berdasarkan uraian latar belakang masalah tersebut penulis ingin mengembangkan Modul dalam penelitian yang berjudul "Pengembangan Modul Ajar Pemrograman Web dengan Konsep Scientific Berorientasi Project Based Learning Di SMK Negeri 2 Seririt.

\section{KAJIAN TEORI}

\section{Modul}

Modul merupakan bahan belajar yang dirancang secara sistematis berdasarkan kurikulum tertentu dan dikemas dalam bentuk satuan pembelajaran terkecil dan memungkinkan dipelajari secara mandiri dalam satuan waktu tertentu ${ }^{[3]}$. Karakteristikmodul diantaranya (1) Self Instruction(2) Self Contained(3) Berdiri sendiri (stand alone) (4) Adaptif (5) Bersahabat/akrab (user friendly) (6)Desain. Untuk membuat sebuah modul maka diperlukan sebuah kerangka agar materi yang disampaikan dapat disajikan secara terstruktur.

\section{Konsep Scientific}

Konsep Scientific adalah konsep dasar yang menginspirasi perumusan metode mengajar dengan menerapkan karakteristik yang ilmiah. Proses pembelajaran Scientific akan menyentuh tiga ranah yaitu : yaitu sikap (afektif), pengetahuan (kognitif), keterampilan (psikomotor). Dengan proses yang demikian diharapkan hasil belajar melahirkan peserta didik yang produktif, kreatif, inovatif dan efektif melalui penguatan sikap dan keterampilan dan pengetahuan yang terintegrasi. Adapun model pembelajaran yang dapat digunakan dalam Konsep 


\section{KARMAPคTI}

Scientific yaitu Discovery Learning (Penemuan), Project Based Learning (Pembelajaran berbasis proyek), dan Problem Based Learning (Pembelajaran berbasis masalah).Melalui konsep Scientific diharapkan pembelajaran dapat meningkatkan hasil belajar siswa seperti yang ditunjukkan pada Gambar 1 .

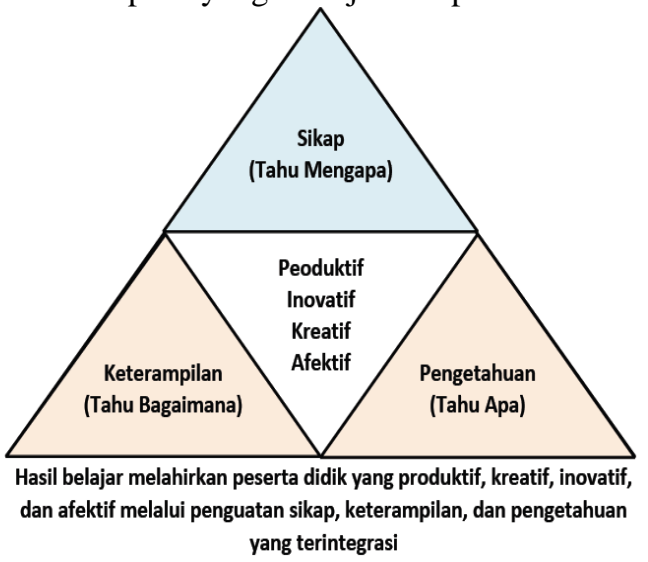

Gambar 1 Proses Pembelajaran Konsep

Scientific(Sumber : Kemdikbud, 2013)

Sesuai dengan Kompetensi Dasar Lulusan, sasaran pembelajaran mencakup pengembangan ranah sikap, pengetahuan, dan keterampilan yang dielaborasi untuk setiap satuan pendidikan. Ketiga ranah kompetensi tersebut memiliki lintasan perolehan (proses psikologi) yang berbeda. Sikap diperoleh melalui aktivitas "menerima, menjalankan, menghargai, menghayati, dan mengamalkan". Pengetahuan diperoleh melalui aktivitas " mengingat, memahami, menerapkan, menganalisis, mengevaluasi, dan mencipta". Keterampilan diperoleh melalui aktivitas "mengamati, menanya, mencoba, menalar, menyaji, dan mencipta". Karakteristik kompetensi beserta perbedaan lintasan perolehan turut serta mempengaruhi karakteristik standar proses (Permen No.65 Tahun 2013). Pendekatan scientific dalam pembelajaran sebagaimana dimaksud meliputi mengamati, menanya, menalar, mencoba, membentuk jejaring untuk semua mata pelajaran. Ditunjukkan pada Gambar 2.

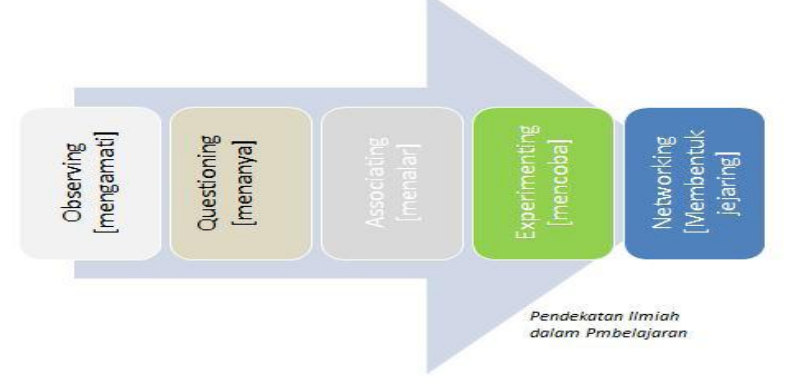

Gambar 2.1 Standar Proses dalam Konsep Scientific Kurikulum 2013
ISSN 2252-9063

(KARMAPATI)

Volume 7, Nomor 3, Tahun 2018

(Sumber : Permen No.65 Tahun 2013,)

\section{Model Pembelajaran Project Based Learning (PjBL)}

Problem Based Learning merupakan model pembelajaran yang menggunakan proyek/kegiatan sebagai media. Guru menugaskan siswa untuk melakukan eksplorasi, penilaian, interpretasi, sintesis, dan informasi untuk menghasilkan berbagai bentuk hasil belajar. Model pembelajaran ini menggunakan masalah sebagai langkah awal dalam mengumpulkan dan mengintegrasikan pengetahuan baru berdasarkan pengalamannya dalam beraktifitas secara nyata. Kegiatan pembelajaran ini dirancang untuk digunakan pada permasalahan komplek yang diperlukan peserta didik dalam melakukan insvestigasi dan memahaminya. Melalui model pembelajaran ini, proses inquiry dimulai dengan memunculkan pertanyaan penuntun (a guiding question) dan membimbing peserta didik dalam sebuah proyek kolaboratif yang mengintegrasikan berbagai subjek (materi). Sistem Penilaian yang dilakukan pada model pembelajaran proyek adalah Penilaian proyek. Penilaian ini merupakan kegiatan penilaian terhadap satu tugas yang harus diselesaiakan dalam kurun waktu tertentu. Penilaian proyek dapat digunakan untuk mengetahui pemahaman, kemampuan mengaplikasikan, kemampuan penyelidikan dan kemampuan menginformasikan peserta didik pada mata pelajaran tertentu secara jelas

\section{Pemprograman Web}

Pemprograman web merupakan salah satu mata pelajaran produktif multimedia di SMK bidang keahlian multimedia. Materi yang diajarkan dalam mata pelajaran tersebut adalah mengenai Teknologi Aplikasi Web, Format Teks Halaman Web, serta Format Tabel halaman web. Materi-materi tersebut tercantum dalam silabus Pemprograman Web. Berikut ini adalah kompetensi inti, kompetensi dasar, dan materi pembelajaran yang akan diimplementasikan pada modul ajar pemprograman web.

\section{III.METODOLOGI}

1. Jenis Penelitian

Penelitian ini merupakan jenis Penelitian Pengembangan atau dalam bahasa Inggrisnya Research and Development ( $\mathrm{R} \& \mathrm{D})$ yakni metode penelitian yang digunakan untuk menghasilkan produk tertentu, dan menguji kefektifan produk tersebut. Pengembangan modul ajar memahami alir proses produksi produk multimedia ini menggunakan model ADDIE. (1) Analysis (analisis) yaitu melakukan analisis kebutuhan, 


\section{ISSN 2252-9063 \\ Kumpulan Artikel MahasiswaPendidikanTeknikInformatika \\ (KARMAPATI) \\ Volume 7, Nomor 3, Tahun 2018}

\section{KARMAPATI}

mengidentifikasi masalah (kebutuhan). (2) Design (desain) modul dialakukan dengan menyususun buram modul. Penulisan modul diawali dengan menyusun buram modul. (3) Development (pengembangan) tahap ini adalah merupakan proses untuk mewujudkan rancangan tersebut menjadi kenyataan.

Implementation (implementasi) ini adalah tahap uji coba modul ajar melalui uji lapangan (5) Evaluation (evaluasi) tahap terakhir adalah melakukan evaluasi yang meliputi evaluasi formatif dan evaluasi sumatif.

\section{Teknik Pengumpulan Data}

Data yang dikumpulkan untuk dianalisis dalam penelitian ini meliputi informasi tentang sumber belajar. Sumberbelajardikumpulkan dengan menggunakan metode wawancara. Metode wawancara digunakan untuk mengetahui secara langsung kurikulum yang berlaku di sekolah serta ketersediaan sumber belajar mata pelajaran memahami pemprograman web yang tertuang dalam bentuk silabus. Adapun sumber data pada saat wawancara tersebut adalah guru yang mengajar mata pelajaran pemprograman web.

\section{Validasi Modul}

Validasi modul di uji oleh ahli isi (expert judgemet), ahli desain, ahli media, uji perorangan dan uji kelompok kecil, menganalisis respon siswa terhadap pengembangan modul.

\section{IV.PEMBAHASAN}

Pengembangan modul ajar pemprograman web bertujuan untuk membantu siswa memahami materi pembelajaran. Selain itu pengembangan modul ajar pemprograman wen dengan konsep scinetifik berorientasi project based learning menggunakan yang bertujuan agar pembelajaran dapat berpusat kepada siswa.

Dalam proses pengembangan modul peneliti menggunakan model pengembangan ADDIE (Analysis, Design, Development, Implementation, Evaluate). Pada tahap Analysis (analisis) peneliti melakukan analisis masalah dan kebutuhan. Masalah yang terjadi adalah tidak adanya bahan ajar yang dapat membelajarkan siswa secara mandiri. Dengan demikian peneliti melakukan alanisis terhadap silabus mata pelajaran pemprograman web untuk memperoleh informasi modul yang dibutuhkan oleh siswa. Dalam melakukan analisis penulis menganalisis silabus kurikulum 2013, dan kurikulum KTSP mengenai kompetensi dasar yang muncul diantara kedua kurikulum hampir tidak ada perbedaan hanya saja perbedaan terletak pada standar Kompetensi dengan Kompetensi Inti, sedangkan untuk kompetensi dasarnya hampir sama anatara KTSP dengan kurikulum 2013. Dari kompetensi dasar kemudian diturunkan menjadi indikator kemudian diturunkan materi. Dengan demikian pada tahap analisis peneliti mendapatkan keluaran berupa kompetensi dasar, indikator dan materi.

Berdasarkan kerangka modul yang telah dibuat peneliti melangkah ke tahap (Development) pengembangan. Pada tahap ini peneliti mengembangkan modul sesuai dengan kerangka modul yang telah dibuat. Materi-materi yang semula dituangkan secara garis besar saja, pada tahap ini materi dikembangkan secara detail untuk mencapai kompatensi dasar. Setelah materi dikembangkan langakah selanjutnya adalah menyusun modul menjadi satu kesatuan. Dengan demikian keluaran yang didapatkan adalah buram modul. Walaupun modul telah selesai dibuat akan tetapi modul tersebut masih dikatakan buram modul karena modul yang tersebut belum valid. Untuk itu perlu dilakukan validasi oleh para ahli yaitu ahli isi, ahli media, dan ahli desain. Selain para ahli validasi dilakukan oleh siswa melalui uji perorangan dan uji kelompok kecil.

Setiap tahap yang dilakukan oleh peneliti tidak terbebas dari kesalahan sehingga setiap tahap dilakukan evaluasi. Evaluasi yang dilakukan adalah evaluasi secara formatif. Tujuan evaluasi formatif adalah untuk memperbaiki modul yang dikembangkan. Evaluasi dilakukan untuk perbaikan-perbaikan sesuai dengan penilaian dan masukan yang diberikan oleh para ahli maupun siswa.

Hasil penilaian ahli isi memberikan penilaian baik hal tersebut mengindikasi materi yang ada di dalam modul relevan untuk digunakan dalam pembelajaran pemprograman web. Hasil penilaian ahli desain memberikan penilaian sangat baik. Hal tersebut membuktikan penerapan project based learning dalam modul sudah sesuai akan tetapi dari masukan yang diberikan oleh ahli desain dapat menyempurnakan modul sehingga modul telah valid dari segi desain. Hasil penilaian ahli media memberikan penilaian baik sehingga dari segi tampilan media modul yang telah dibuat telah sesuai. Beberapa masukan seperti jenis font dan ukuran font telah dilakukan perubahan agar modul valid dari segi media. Penilaian siswa melalui uji perorangan dan kelompok kecil terhadap modul ajar pemprograman web ini memeberikan respon sangat baik. Respon ini mengindikasi bahwa siswa merasa terbantu dalam memahai materi.

Setelah melalui proses pengembangan dan pengujian oleh para ahli dan siswa maka tahap selanjutnya adalah tahap Implementation (implementasi) melalui uji lapangan. Implementasi modul ini dilakukan untuk mendapatkan respon siswa terhadap pengembangan modul ajar pemprograman web berorientasi project based learning. Siswa dibelajarkan dengan modul pemprograman web. Diawali dengan pembagian modul ke masing-masing siswa. Pada saat implementasi dilakukan 1 (satu) kegiatan pembelajaran, yaitu Kegiatan Pembelajaran 1 yang berjudul 


\section{KARMAPATI}

Teknologi Aplikasi Web. Langkah pertama siswa membentuk kelompok, siswa diarahkan membuat kelompok kemuadian siswa diarahkan untuk diskusi dengan kelompoknya untuk menjawab pertanyaanpetanyaan seputar pengetahuan awal siswa. Langkah kedua merencanakan kegiatan kelompok, siswa diarahkan untuk menentukan topik projek kelompok menemukan ide pembelajaran dengan membaca materi dari hasil membaca materi siswa dapat menentukan usulan topik projek dan rancangan projek kelompok.. Langkah ketiga melakukan investigasi, siswa membaca materi pada kegiatan pembelajaran 2 (dua) yaitu format teks siswa melakukan investigasi terhadap permasalahan topik yang dibuat dan guru membimbing siswa terhadap permasalahan yang dihadapi . Langkah keempat merencanakan laporan, siswa membaca materi pada kegiatan pembelajaran 3 (tiga) kemudian dari hasil membaca materi siswa merencanakan laporan projek dari topik yang telah dibuat dan guru membimbing siswa dalam merencanakan laporan projek. Langkah kelima presentasi, siswa melakukan presentasi laporan projek dengan kelompoknya di depan kelas. Langkah keenam evaluasi untuk mengetahui tingkat pemahaman/ pengetahuan siswa.

Setelah selesai melaksanakan pembelajaran menggunakan modul melalui angket siswa memberikan respon penilain dengan hasil baik terhadap modul. Selain hal tersebut penilaian juga dinyatakan dalam komentar dan saran yang diberikan oleh siswa yang menyatakan modul dapat membatu dalam memahami materi. Dengan terbantunya siswa dalam memahami materi mengindikasi bahwa modul relevan digunakan dalam pembelajaran.

Secara garis besar para siswa memandang bahwa pengembangan modul ajar pemprograman web telah dibuat menunjukan adanya keberhasilan, dan hal ini terbukti dengan pernyataan siswa yaitu keberadaan modul sangat membantu dalam proses belajar. Dapat menyediakan bahan ajar, memandirikan siswa dalam belajar sehingga pembelajaran tidak hanya berpusat pada guru. Dengan demikian peneliti berhasil mengembangkan modul ajar pemprograman web dengan konsep scientific berorientasi PjBL yang valid

\section{SIMPULAN}

Pengembangan modul ajar pempograman web dengan kosep scientificberorientasi PjBL dirancang untuk menyediakan sumber belajar bagi siswa untuk memahami materi pempograman web. Dengan kosep scientificberorientasi PjBL modul dapat membelajarkan siswa secara mandiri sehingga pembelajaran dapat berpusat pada siswa. Melalui uji lapangan siswa memberikan penilaian dengan rata-rata persentase $89 \%$ sehingga jika dikonversikan persentase tersebut dalam kualifikasi baik.
ISSN 2252-9063

(KARMAPATI)

Volume 7, Nomor 3, Tahun 2018

\section{REFERENSI}

[1] Ayriza, Yulia. 2008. "Developing And Validating The Social Life Skill Module For PreSchool Educators". Jurnal Penelitian dan Evaluasi Pendidikan, Nomor 2, Tahun XII. (hlm 218-219)

[2] Direktorat Pembinaan Sekolah Menengah Kejuruan Departemen Pendidikan Nasional. 2008. Teknik Penyusunan Modul. Seri Bahan Bimbingan Teknis Implementasi KTSP. Jakarta: Direktorat Jendral Manajemen Pendidikan Dasar dan Menengah

[3] Kertiasih, Ni Ketut .2009. "Pengembangan Media Pembelajaran Berbasis Multimedia Gerakan Dasar Tari Bali”. http://ejournal.undiksha.ac.id/index.phpJPTK/ar ticle/download/18/17 (diakses tangga 20 Pebruari 2014)

[4] Santyasa, I Wayan. 2009." Metode Penelitian Pengembangan dan Teori Pengembangan Modul". Makalah disajikan dalam Pelatihan bagi Para Guru TK, SMP,SMA, dan SMK tanggal 1214 Januari di Kecamatan Nusa Penida Kabupaten Klungkung, Undiksha Singaraja

[5] Tegeh dan Kirna. 2012. Pengembangan bahan Ajar Metode Penelitian Pendidikan Dengan Model ADDIE. Terdapat pada http://ejournal.undiksha.ac.id/index.php/IKA/arti cle/view/1145/1008. (diakses tanggal 5 januari 2014) 